\title{
Two new species of Phyllanthus (Phyllanthaceae) from Thailand
}

\author{
Pimwadee Pornpongrungrueng', Pranom Chantaranothai', \\ John A.N. Parnell2, Trevor R. Hodkinson ${ }^{2}$
}

I Applied Taxonomic Research Center, Department of Biology, Faculty of Science, Khon Kaen University, Khon Kaen 40002, Thailand 2 Herbarium, Department of Botany, School of Natural Sciences, and Trinity Centre for Biodiversity Research, Trinity College Dublin, the University of Dublin, Dublin 2, Ireland

Corresponding author: Pimwadee Pornpongrungrueng (ppimwa@kku.ac.th)

Academic editor:A. Sennikov | Received 25 October 2019 | Accepted 27 November 2019 | Published 11 December 2019

Citation: Pornpongrungrueng P, Chantaranothai P, Parnell JAN, Hodkinson TR (2019) Two new species of Phyllanthus (Phyllanthaceae) from Thailand. PhytoKeys 136: 35-44. https://doi.org/10.3897/phytokeys.136.47625

\begin{abstract}
Two Phyllanthus species are newly described from a limestone mountain in the north of Thailand. The first species, P. huamotensis Pornp., Chantar. \& J.Parn., sp. nov., is one of the most distinct Phyllanthus species easily distinguished by its reddish branchlets and stem, conspicuous reddish venation, especially on the lower leaf surface, red sepals with long fimbriate margin and red capsule with papillose-puberulous surface. The second species, P. chantaranothaii Pornp., J.Parn. \& Hodk., sp. nov., is similar to P. pulcher Wall. ex Müll. Arg., but it is distinguished by its puberulous upper leaf surface and pistillate flowers which have red, narrowly lanceolate sepals with a white, long fimbriate margin, puberulous outer side as well as puberulous pedicel.
\end{abstract}

\section{Keywords}

diversity, Euphorbiaceae, new taxa, revision, taxonomy

\section{Introduction}

Phyllanthus L. (Phyllanthaceae) is mainly distributed in tropical and subtropical regions (Radcliffe-Smith 2001; Webster 2014). The classification of Phyllanthus is still contentious (Kawakita and Kato 2017) because molecular phylogenetic studies have indicated that Phyllanthus, as previously circumscribed, was not monophyletic (Kathriarachchi et al. 2006). Therefore, some authors suggested merging other closely related 
genera in Phyllanthus, such as Breynia J.R.Forst. \& G.Forst., Glochidion J.R.Forst. \& G.Forst. and Sauropus Blume (Hoffmann et al. 2006), while others suggested division of Phyllanthus into several monophyletic and morphologically recognisable genera (Pruesapan et al. 2012; van Welzen et al. 2014). The most recent publication by Bouman et al. (2018) recorded 880 species of Phyllanthus and, amongst these, they were able to place 837 species in 18 subgenera, 70 sections and 14 subsections; 43 species remained unassigned. Phyllanthus is, therefore, one of the most diverse genera of flowering plants and its species often have a high degree of endemism. For example, in China, there are about 32 species reported, 13 of which are endemic (Li and Gilbert 2008). Thirty-six species of Phyllanthus s.str. (excluding Breynia, Glochidion and Sauropus) were reported for the Flora of Thailand by Chantaranothai (2007). Lately, two more new species have been included by Kantachot and Chantaranothai (2013) and Pornpongrungrueng et al. (2017). Thus, the total Thai species number has increased to 38, five of which are endemic to Thailand. Recently, two Phyllanthus taxa were discovered in Umpang district, Tak province, in the northern part of Thailand; they were investigated and are described herein as new species.

\section{Methods}

Field collections and herbarium specimens from various herbaria, as well as taxonomic literature, were examined. The herbarium abbreviations follow Index Herbariorum (Thiers 2019, continuously updated). The morphological descriptions and measurements were taken from dried specimens.

\section{Results}

\section{Taxonomic treatment}

\section{Phyllanthus huamotensis Pornp., Chantar. \& J.Parn., sp. nov.} urn:Isid:ipni.org:names:77203519-1

Figs 1, 2

Diagnosis. Phyllanthus huamotensis is one of the most distinct species of Phyllanthus in Thailand, easily distinguished by its reddish branchlets and stem, conspicuous reddish venation, especially on the lower leaf surface, red sepals with long fimbriate margins and red capsule with a papillose-puberulous surface. It is most similar to $P$. pulcher Wall. ex Müll.Arg., but differs in its undershrub habit that is up to $30 \mathrm{~cm}$ high ( $P$. pulcher is a shrub up to $1.5 \mathrm{~m}$ high), small sized leaves $(2-9 \times(2-) 3-8 \mathrm{~mm})$ (leaves in P. pulcher are 7-28 $\times 6-17 \mathrm{~mm}$ ) with conspicuous reddish venation (inconspicuous on both leaf surfaces in $P$. pulcher) and a red capsule with a papillose-puberulous surface (glabrous in $P$. pulcher). 


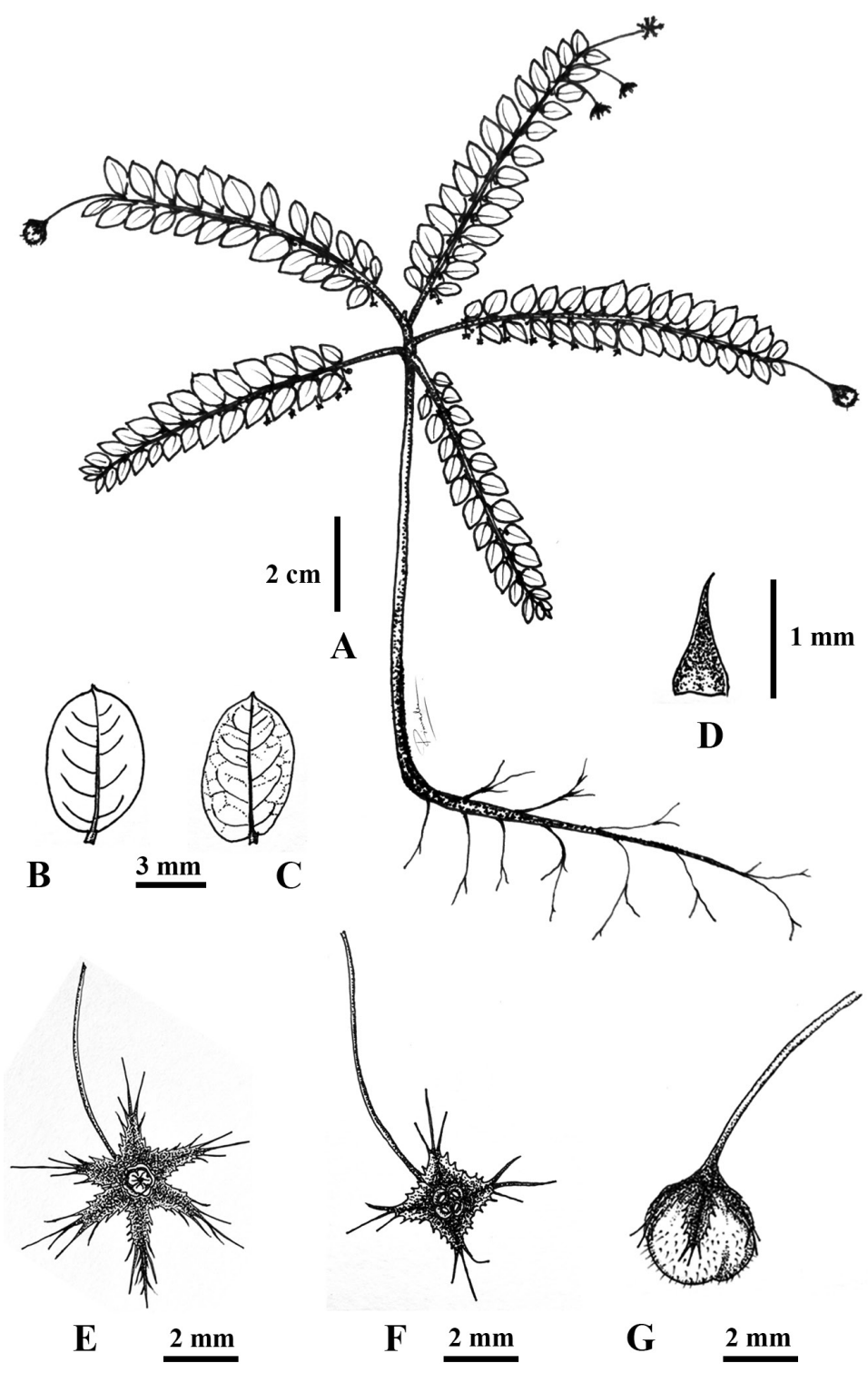

Figure I. Phyllanthus huamotensis Pornp., Chantar. \& J.Parn., sp. nov. A habit B, C leaf shapes (B adaxial surface $\mathbf{C}$ abaxial surface) $\mathbf{D}$ stipule $\mathbf{E}$ pistillate flower $\mathbf{F}$ staminate flower $\mathbf{G}$ mature capsule. Drawn by Pimwadee Pornpongrungrueng.

Type. Thailand. Tak, Umpang district, Doi Hua Mot; $16^{\circ} 2.63^{\prime} \mathrm{N}, 98^{\circ} 51.26^{\prime} \mathrm{E}$; alt. 901 m; 22 Aug. 2019; P. Pornpongrungrueng, N. Triyutthachai, S. Ninkaew \& S. Sukcharoen 1287 (bolotype KKU; isotypes BKF, K, QBG, TCD).

Description. Undershrubs up to $30 \mathrm{~cm}$ high, branchlets and stem reddish, terete, young branchlets minutely puberulous. Stipules triangular-lanceolate, $0.5-1 \times 0.3-0.5$ 


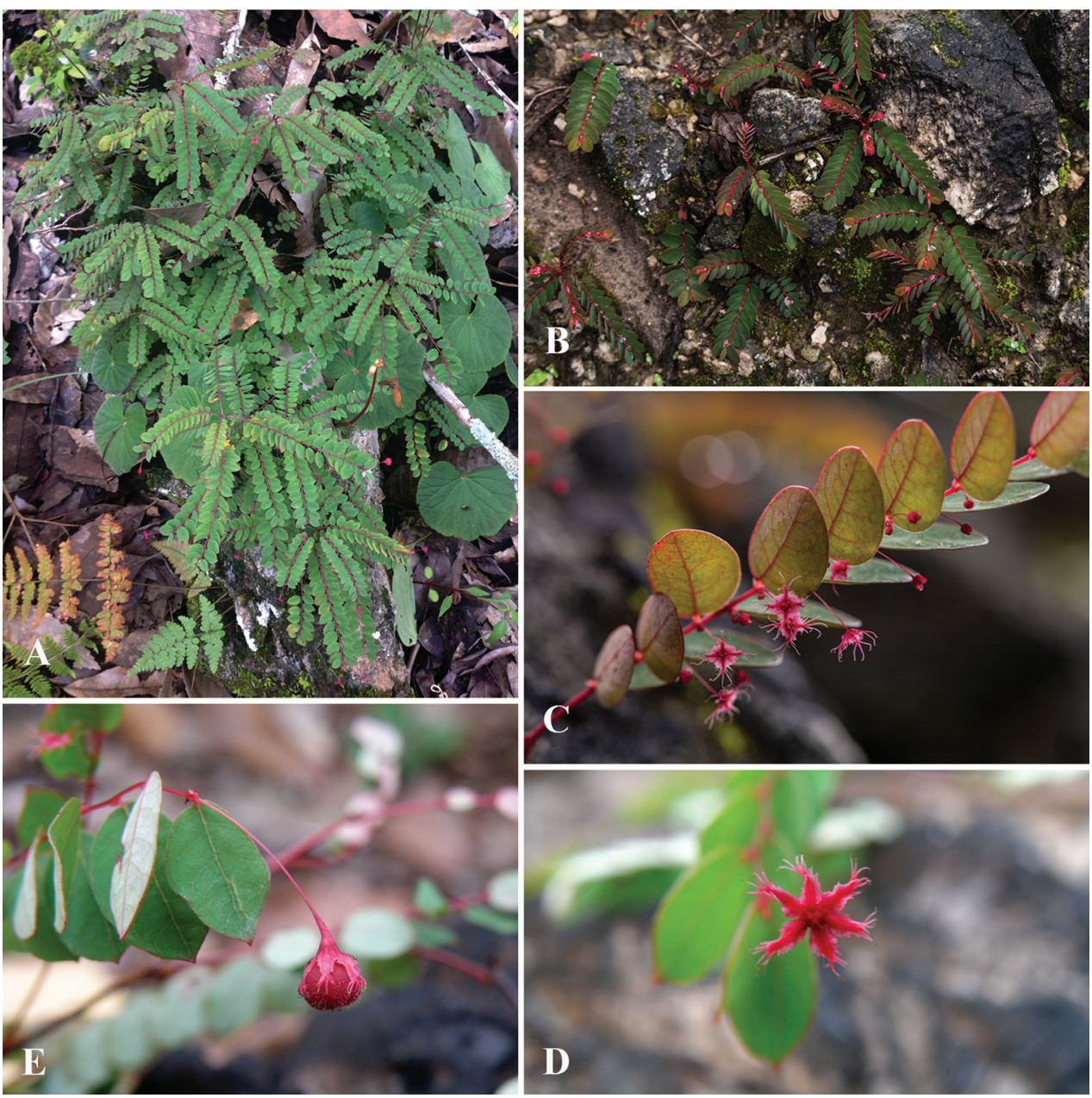

Figure 2. Phyllanthus huamotensis Pornp., Chantar. \& J.Parn., sp. nov. A, B habit $\mathbf{C}$ branchlet showing axillary fascicle of staminate flowers $\mathbf{D}$ branchlet showing pistillate flower $\mathbf{E}$ branchlet showing young red capsule. A Photo by Natthawut Triyuttachai B, C photos by Suchart Chanhomhual D, E photos by Kanokorn Ruengsawang.

$\mathrm{mm}$, glabrous. Leaves alternate; petioles $0.4-0.9 \mathrm{~mm}$ long, glabrous; lamina broadly ovate, obovate, rounded, broadly elliptic, ovate-oblong, 2-9 $\times(2-) 3-8 \mathrm{~mm}$, subcoriaceous, glabrous on both surfaces, base oblique, cordate, broadly cuneate, truncate, rounded, margin entire, revolute, apex acute, acuminate, rounded; nerves in 4-6 pairs; reticulation reddish, conspicuous, especially on the lower surface. Flowers red, unisexual; staminate flowers 2-3(-4) in axillary fascicles in proximal axils; pistillate flower solitary in distal axils. Bracts subulate, $0.2-0.3 \times 0.1-0.2 \mathrm{~mm}$, glabrous. Staminate flowers: pedicel 4-10 mm long, glabrous; sepals 4, red, triangular, rhombic-ovate, lanceolate, 1.5-2 × 1-1.2 mm, glabrous, margin long fimbriate; disc glands 4, reniform; stamens 
4, staminal column ca. $0.2 \mathrm{~mm}$ long, anthers ca. $0.2 \mathrm{~mm}$ long, transversely dehiscent. Pistillate flowers: pedicel 7-17 mm long, glabrous; sepals 5-6, red, rhombic-ovate, $1.5-3 \times 0.6-1 \mathrm{~mm}$, membranous, glabrous, margin fimbriate; disc glands 5 or 6 , free, obovate with truncate apex; ovary superior, ca. $0.7 \mathrm{~mm}$ diam., 3-locular, ovules 2 per locule, papillose-puberulous; styles 3 , free, ca. $0.1 \mathrm{~mm}$ long; stigmas nearly completely bifid, ca. $0.2 \mathrm{~mm}$ long, glabrous. Fruits capsule, red, 2.5-3 mm diam., papillosepuberulous; pedicel 7-17 mm long. Seeds trigonous, brown, 1.5-1.8 × 1.1-1.2 mm, surface transversely striate.

Phenology. Flowering and fruiting period is June to December.

Habitat and distribution. This species grows on open limestone hills, at 880-937 $\mathrm{m}$ above sea level. Currently, it is known only from the type location Doi Huamot, Tak province in northern Thailand.

Conservation status. The species is only known from the type locality. It should be categorised as Critically endangered [CR, B1ab (iii)] according to the IUCN Red List Criteria and Categories version 3.1 (IUCN 2012). The extent of occurrence is estimated to be less than $20 \mathrm{~km}^{2}$ and this species is found in a restricted area on open limestone hills which is a threatened ecosystem.

Etymology. The name of this species is given, based on the location where the plant was first discovered.

Vernacular. Ma Kham Pom Din Huamot.

Additional specimens examined. Thailand: Tak, Umpang district, Doi Hua Mot; 1556.46'N, 9851.93'E; alt. 937 m; 2 Dec. 2018; P. Pornpongrungrueng, N. Triyutthachai \& P. Chantaranothai 1270 (BKF, KKU), ibid.; 1551.40'N, 98 50.88'E; alt. 882 m; 22 Aug. 2019; P. Pornpongrungrueng, S. Ninkaew, S. Sukcharoen \& N. Triyutthachai 1285 (BKF, KKU, TCD).

\section{Phyllanthus chantaranothaii Pornp., J.Parn. \& Hodk., sp. nov.} urn:lsid:ipni.org:names:77203520-1

Figs 3, 4

Diagnosis. Phyllanthus chantaranothaii is most similar to $P$. pulcher, but differs in its puberulous upper leaf surface with white, simple and dendritic hairs and pistillate flowers that have red, narrowly lanceolate sepals with a white long fimbriate margin, puberulous on the outer side and puberulous pedicel, whereas in $P$. pulcher, the leaf is glabrous on both surfaces and the sepals of the pistillate flower are rhombic-ovate with the upper part greenish and lower part red, glabrous on the outside and glabrous pedicel.

Type. Thailand. Tak, Umpang district, Pa La Ta waterfall, $15^{\circ} 49.14^{\prime} \mathrm{N}, 98^{\circ} 51.37^{\prime} \mathrm{E}$, alt. ca. 500 m, 23 Aug. 2019, P. Pornpongrungrueng, S. Ninkaew, S. Sukcharoen \& N. Triyuthachai 1291 (bolotype KKU; isotypes BKF, K, QBG, TCD).

Description. Small shrubs up to $80 \mathrm{~cm}$ high, branchlets terete, young branchlets puberulous with white, simple and dendritic hairs. Stipules lanceolate-subulate, 1.4-2 $\times$ 


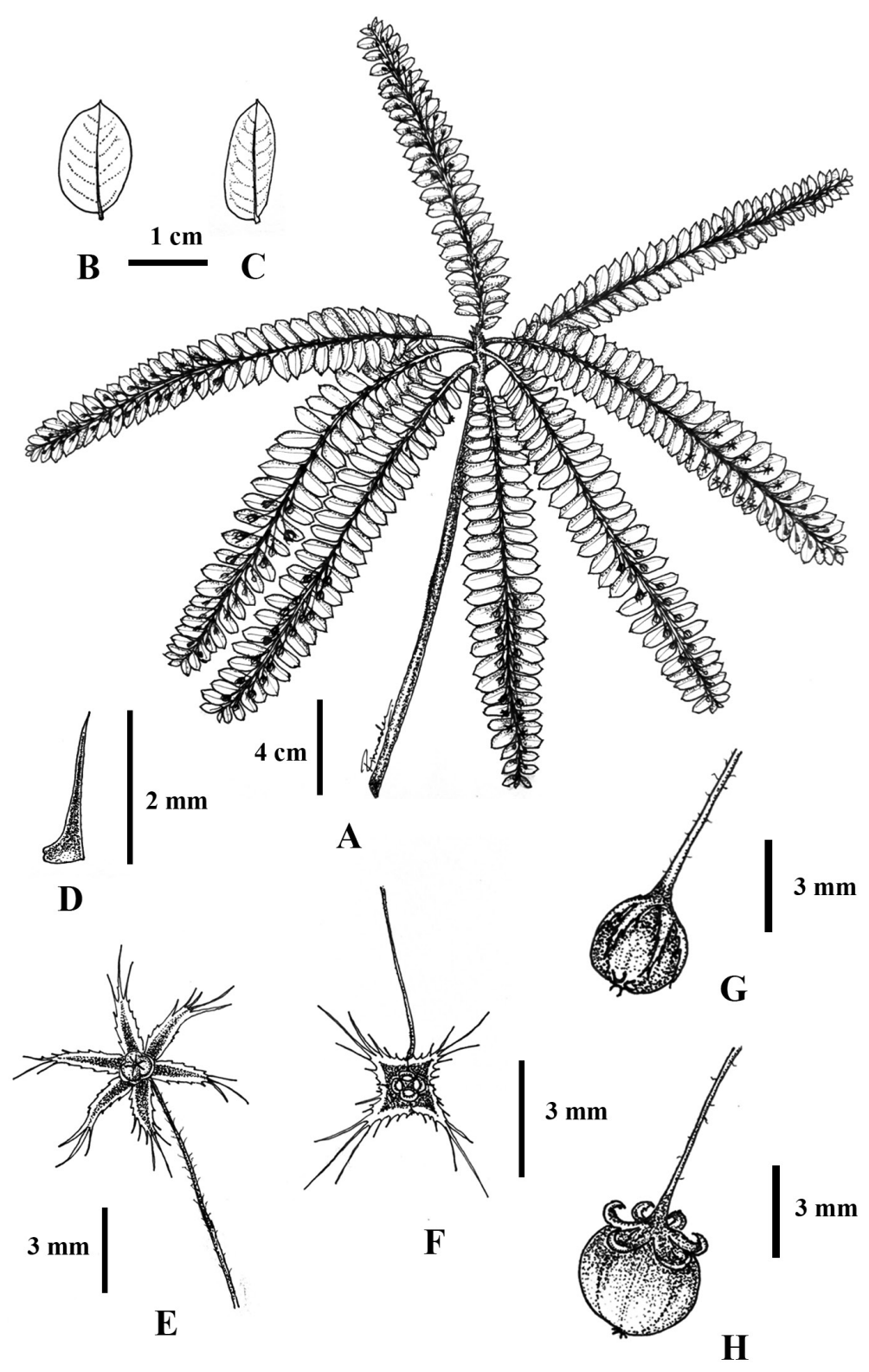

Figure 3. Phyllanthus chantaranothaii Pornp., J.Parn. \& Hodk., sp. nov. A habit B, C leaf shapes (B adaxial surface $\mathbf{C}$ abaxial surface) $\mathbf{D}$ stipule $\mathbf{E}$ pistillate flower $\mathbf{F}$ staminate flower $\mathbf{G}$ young capsule $\mathbf{H}$ mature capsule. Drawn by Pimwadee Pornpongrungrueng.

0.1-0.4 mm, glabrous. Leaves alternate; petioles ca. $0.5 \mathrm{~mm}$ long, glabrous; lamina oblong, obovate, $1-2.1 \times 0.5-0.8 \mathrm{~cm}$, membranous, upper surface puberulous with white, simple and dendritic hairs, lower surface glabrous, base oblique, margin entire, revolute, apex mucronate; nerves in 4-7 pairs; reticulation inconspicuous on both sur- 

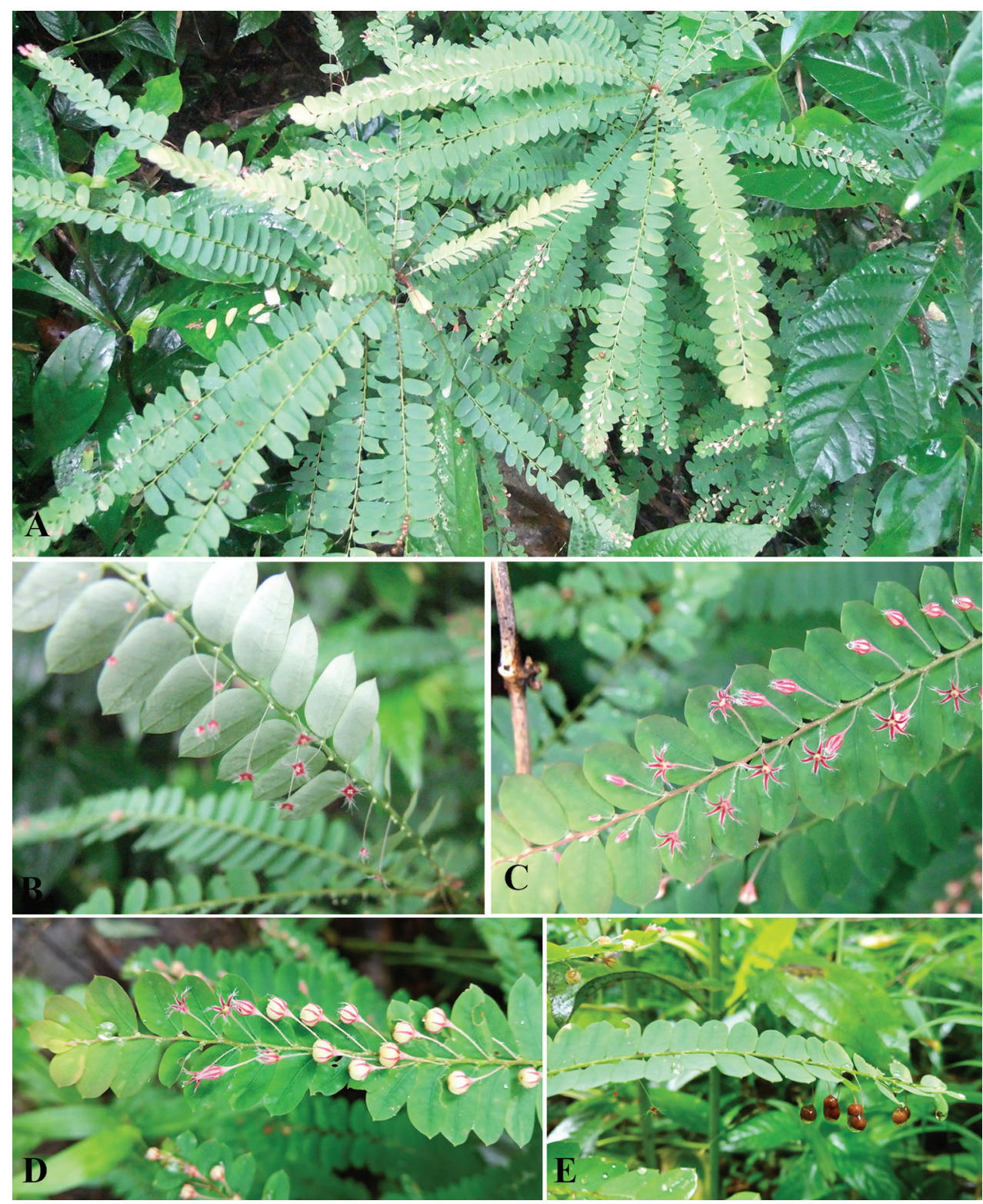

Figure 4. Phyllanthus chantaranothaii Pornp., J.Parn. \& Hodk., sp. nov. A habit B branchlet showing axillary fascicle of staminate flowers $\mathbf{C}$ branchlet showing pistillate flower $\mathbf{D}$ branchlet showing young capsule $\mathbf{E}$ branchlet showing mature capsule. A-C photos by Natthawut Triyuttachai $\mathbf{D}, \mathbf{E}$ photos by Siriyakorn Sukcharoen.

faces. Flowers unisexual; staminate flowers $2-3$ in axillary fascicles along lower half of the branchlets; pistillate flower solitary in leaf-axils along upper half of the branchlets. Bracts subulate, $0.6-1.4 \times$ ca. $0.2 \mathrm{~mm}$, puberulous-glabrous. Staminate flowers: pedicel 5-11 mm long, glabrous; sepals 4, red, triangular, rhombic-ovate, $2-3 \times$ ca. $1 \mathrm{~mm}$, 
glabrous, margin white long fimbriate; disc glands 4, reniform; stamens 4, staminal column ca. $0.2 \mathrm{~mm}$ long, anthers ca. $0.2 \mathrm{~mm}$ long, transversely dehiscent. Pistillate flowers: pedicel $8-11 \mathrm{~mm}$ long, puberulous; sepals 6 , reddish, narrowly lanceolate, 3-3.5 $\times$ $0.5-0.8 \mathrm{~mm}$, outer surface puberulous, margin white long fimbriate; disc glands 6 , free, obovate with truncate apex; ovary superior, ca. $1 \mathrm{~mm}$ diam., 3-locular, ovules 2 per locule, glabrous or papillose; styles 3 , free, ca. $0.1 \mathrm{~mm}$ long; stigmas nearly completely bifid, $0.4-0.6 \mathrm{~mm}$ long, glabrous. Fruits capsule, young capsule white to pale greenish, $2.5-4 \mathrm{~mm}$ diam., glabrous or papillose; pedicel 5-13 mm long. Seeds trigonous, brown, $1.5-2 \times 1-1.3 \mathrm{~mm}$, surface transversely striate.

Phenology. Flowering and fruiting from August to November.

Habitat and distribution. This species grows in mixed deciduous forest, at ca. $500 \mathrm{~m}$ elevation. It is currently known from the type location near $\mathrm{Pa} \mathrm{La} \mathrm{Ta}$ waterfall and Doi Huamot, Tak province, Thailand.

Conservation status. As only the type collection, which was collected from mixed deciduous forest, has been investigated in detail, more field exploration in similar habitats in the surrounding areas should be conducted in order to provide a more accurate distribution range of this species. However, based on information that is available to us, this species is preliminarily categorised here as Endangered [EN, B1ab(i, iv)], according to the IUCN Red List Criteria and Categories version 3.1 (IUCN 2012). The extent of occurrence is estimated to be less than $50 \mathrm{~km}^{2}$ and, previously, it was found in two locations (Doi Huamot and Pa La Ta waterfall in Umpang district, Tak province), but recently, the extent of occurrence seems to be in decline, because the species has not been found in Doi Huamot since it was first photographed in November 2008.

Etymology. The name of this species honours Prof. Dr. Pranom Chantaranothai for his major contributions to plant taxonomy, in general, but especially for his extensive work on Phyllanthus in the Flora of Thailand.

Vernacular. Mayom Noi.

\section{Discussion}

The two species described herein should be classified in subgenus Eriococcus (Hassk.) Croizat \& Metcalf and Section Eriococcus (Hassk.) Croizat \& Metcalf, because they have staminate flowers composed of four sepals with a long fimbriate margin, four stamens with transversely dehiscent anthers and the stigmas in pistillate flowers are free and bifid. These are diagnostic characters of the section Eriococcus which occurs predominantly in mainland Asia, especially in Indochina (Kawakita and Kato 2017; Bouman et al. 2018). Prior to this paper, there were seven species recorded in Thailand that belonged to this section, including P. elegans Wall. ex Müll.Arg., P. gracilipes (Miq.) Müll.Arg., P. pulcher, P. pulchroides Beille, P. sikkimensis Müll.Arg., P. sootepensis and P. taxodiifolius Beille (Chantaranothai 2007; Bouman et al. 2018). The two newly described species are most similar to $P$. pulcher, but there are a number of different characters as presented in Table 1. Actually, P. huamotensis is one of the most distinct 
Table I. Comparison of morphological characteristics of $P$. huamotensis, $P$. chantaranothaii and $P$. pulcher.

\begin{tabular}{|c|c|c|c|}
\hline Characters & P. huamotensis & P. chantaranothaii & P. pulcher \\
\hline habit & undershrubs up to $30 \mathrm{~cm}$ high & small shrubs up to $80 \mathrm{~cm}$ high & shrubs up to $1.5 \mathrm{~m}$ high \\
\hline branchlet & $\begin{array}{l}\text { young branchlets minutely } \\
\text { puberulous with simple hairs }\end{array}$ & $\begin{array}{c}\text { young branchlets puberulous } \\
\text { with white, simple and dendritic } \\
\text { hairs }\end{array}$ & $\begin{array}{l}\text { young branchlets puberulous } \\
\text { with white dendritic hairs }\end{array}$ \\
\hline leaf shape & $\begin{array}{l}\text { broadly ovate, obovate, rounded, } \\
\text { broadly elliptic, ovate-oblong }\end{array}$ & oblong, obovate & oblong to elliptic \\
\hline leaf size & $2-9 \times(2) 3-8 \mathrm{~mm}$ & $10-21 \times 5-8 \mathrm{~mm}$ & $7-28 \times 6-17 \mathrm{~mm}$ \\
\hline leaf texture & subcoriaceous & membranous & subcoriaceous \\
\hline leaf base & $\begin{array}{l}\text { oblique, cordate, broadly } \\
\text { cuneate, truncate, rounded }\end{array}$ & oblique & oblique \\
\hline leaf apex & acute, acuminate, rounded & mucronate & abruptly mucronate \\
\hline upper leaf surface & glabrous & $\begin{array}{l}\text { puberulous with white, simple } \\
\text { and dendritic hairs }\end{array}$ & glabrous \\
\hline leaf reticulation & $\begin{array}{c}\text { conspicuous, especially on lower } \\
\text { surface }\end{array}$ & inconspicuous on both surfaces & inconspicuous on both surfaces \\
\hline $\begin{array}{l}\text { staminate flower } \\
\text { arrangement }\end{array}$ & $\begin{array}{l}2-3(4) \text { flowers in axillary fascicle } \\
\text { along lower half of the branchlets }\end{array}$ & $\begin{array}{c}\text { 2-3 flowers, in axillary fascicle } \\
\text { along lower half of the branchlets }\end{array}$ & $\begin{array}{c}\text { 2-6 flowers in axillary fascicle in } \\
\text { proximal axils }\end{array}$ \\
\hline $\begin{array}{l}\text { staminate flower } \\
\text { pedicel }\end{array}$ & $4-10 \mathrm{~mm}$ long, glabrous & 5-11 mm long, glabrous & 6-15 mm long, glabrous \\
\hline $\begin{array}{l}\text { staminate flower } \\
\text { sepal }\end{array}$ & $\begin{array}{l}\text { 4, red, triangular, rhombic- } \\
\text { ovate, } 1.5-2 \times 1-1.2 \mathrm{~mm} \text {, long } \\
\text { fimbriate margin }\end{array}$ & $\begin{array}{l}\text { 4, red, triangular, rhombic-ovate, } \\
2-3 \times 1 \mathrm{~mm} \text {, long fimbriate } \\
\text { margin }\end{array}$ & $\begin{array}{c}\text { (3) } 4 \text {, red, triangular or ovate, } \\
2-3 \times 1-1.6 \mathrm{~mm} \text {, long fimbriate } \\
\text { margin }\end{array}$ \\
\hline $\begin{array}{l}\text { pistillate flower } \\
\text { arrangement }\end{array}$ & solitary in distal axils & $\begin{array}{c}\text { solitary in leaf-axils along upper } \\
\text { half of the branchlets }\end{array}$ & solitary in distal axils \\
\hline $\begin{array}{l}\text { pistillate flower } \\
\text { pedicel }\end{array}$ & 7-17 mm long, glabrous & $8-11 \mathrm{~mm}$ long, puberulous & 14-25 mm long, glabrous \\
\hline $\begin{array}{l}\text { pistillate flower } \\
\text { sepal }\end{array}$ & $\begin{array}{l}5-6 \text {, red, rhombic-ovate, } 1.5-3 \times \\
0.6-1 \mathrm{~mm} \text {, glabrous }\end{array}$ & $\begin{array}{l}\text { 6, reddish, narrowly lanceolate, } \\
3-3.5 \times 0.5-0.8 \mathrm{~mm} \text {, outer } \\
\text { surface puberulous }\end{array}$ & $\begin{array}{l}\text { (5)6, lower part red, upper part } \\
\text { greenish, rhombic-ovate, } 2-4.5 \times \\
1.1-2.5 \mathrm{~mm} \text {, glabrous }\end{array}$ \\
\hline ovary & papillose-puberulous & glabrous or papillose & glabrous \\
\hline styles & ca. $0.1 \mathrm{~mm}$ long & ca. $0.1 \mathrm{~mm}$ long & ca. $0.1 \mathrm{~mm}$ long \\
\hline stigma & ca. $0.2 \mathrm{~mm}$ long & $0.4-0.6 \mathrm{~mm}$ long & $0.3-0.4 \mathrm{~mm}$ long \\
\hline capsule & $\begin{array}{l}\text { young capsule red, } 2.5-3 \mathrm{~mm} \\
\text { diam., papillose-puberulous }\end{array}$ & $\begin{array}{l}\text { young capsule white to pale } \\
\text { greenish, } 2.5-4 \text { mm diam., } \\
\text { glabrous or papillose }\end{array}$ & $\begin{array}{l}\text { young capsule light greenish-red, } \\
\text { ca. } 2.5 \mathrm{~mm} \text { diam., glabrous }\end{array}$ \\
\hline seed & $1.5-1.8 \times 1.1-1.2 \mathrm{~mm}$ & $1.5-2 \times 1-1.3 \mathrm{~mm}$ & $2-3 \times 0.3-0.5 \mathrm{~mm}$ \\
\hline
\end{tabular}

species of Phyllanthus in Thailand. It can be easily distinguished by its reddish branchlets and stem, conspicuous reddish venation, especially on the lower leaf surface, red sepals with long fimbriate margin and red capsule with papillose-puberulous surface.

\section{Acknowledgements}

We would like to thank the curators of BKF, KKU, QBG and TCD herbaria. This study was supported by the Faculty of Science, Khon Kaen University and the Department of Botany, School of Natural Sciences, Trinity College Dublin, the University of Dublin. The first author would like to thank Suchart Chanhomhual, Natthawut Triyutthachai, Kanokorn Ruengsawang and Witsanu Saisorn for their kind help in the field survey and during preparation of this manuscript. 


\section{References}

Bouman RW, Kessler PJA, Telford IRH, Bruhl JJ, van Welzen PC (2018) Subgeneric delimitation of the plant genus Phyllanthus (Phyllanthaceae). Blumea 63(2): 167-198. https://doi. org/10.3767/blumea.2018.63.02.14

Chantaranothai P (2007) Phyllanthus. In: van Welzen PC, Chayamarit K (Eds) Flora of Thailand. Vol. 8 part 2. The Forest Herbarium, National Park, Wildlife and Plant Conservation Department, Bangkok, 473-507.

Hoffmann P, Kathriarachchi H, Wurdack KJ (2006) A phylogenetic classification of Phyllanthaceae (Malpighiales; Euphorbiaceae sensu lato). Kew Bulletin 61: 37-53. https://www. jstor.org/stable/20443245

IUCN (2012) IUCN Red List Categories and Criteria: Version 3.1 ( $2^{\text {nd }}$ edn). Gland and Cambridge, $32 \mathrm{pp}$.

Kantachot C, Chantaranothai P (2013) A new species of Phyllanthus chayamaritiae (Phyllanthaceae) from Thailand. Blumea 57(3): 217-220. https://doi.org/10.3767/000651913X663280

Kathriarachchi H, Samuel R, Hoffmann P, Mlinarec J, Wurdack KJ, Ralimanana H, Stuessy TF, Chase MW (2006) Phylogenetics of tribe Phyllantheae (Phyllanthaceae; Euphorbiaceae sensu lato) based on nrITS and plastid matK DNA sequence data. American Journal of Botany 93(4): 637-655. https://doi.org/10.3732/ajb.93.4.637

Kawakita A, Kato M (2017) Diversity of Phyllanthaceae Plants. In: Kato M, Kawakita A (Eds) Obligate Pollination Mutualism, Ecological Research Monographs, Springer, Tokyo, 81116. https://doi.org/10.1007/978-4-431-56532-1_4

Li PT, Gilbert MG (2008) Phyllanthus. In: Wu ZY, Raven PH, Hong DY (Eds) Flora of China Vol. 11, Science Press, Beijing and Missouri Botanical Garden, St. Louis, 180-190.

Pornpongrungrueng P, Parnell JAN, Hodkinson TR, Chantaranothai P (2017) Phyllanthus kaweesakii (Phyllanthaceae), a new species from Thailand. Botany 95(6): 567-577. https:// doi.org/10.1139/cjb-2016-0298

Pruesapan K, Telford IRH, Bruhl JJ, van Welzen PC (2012) Phylogeny and proposed circumscription of Breynia, Sauropus and Synostemon (Phyllanthaceae), based on chloroplast and nuclear DNA sequences. Australian Systematic Botany 25(5): 313-330. https://doi. org/10.1071/SB11005

Radcliffe-Smith A (2001) Genera Euphorbiacearum. Royal Botanic Gardens, Kew.

Thiers B (2019) [continuously updated] Index Herbariorum: a global directory of public herbaria and associated staff. New York Botanical Garden's Virtual Herbarium. The New York Botanical Garden. http://sweetgum.nybg.org/science/ih/

van Welzen PC, Pruesapan K, Telford IRH, Esser H-J, Bruhl JJ (2014) Phylogenetic reconstruction prompts taxonomic changes in Sauropus, Synostemon and Breynia (Phyllanthaceae tribe Phyllantheae). Blumea 59(2): 77-94. https://doi.org/10.3767/000651914X684484

Webster GL (2014) Euphorbiaceae. In: Kubitzki K (Ed.) The Families and Genera of Vascular Plants. Vol. 11. Springer, Heidelberg, 51-216. https://doi.org/10.1007/978-3-64239417-1_10 